\title{
Restoration of Tourism in Indonesia New Normal Era Through CHS Program in Bali Tourism
}

\author{
Erny Rosmiyanti*, Sri Sutjiatmi, Calista Qotrunada Azzahra \\ Universitas Pancasakti Tegal, Indonesia \\ Corresponding author.Email: rosyantierny@gmail.com
}

\begin{abstract}
The COVID-19 pandemic is a worldwide epidemic that has altered people's life systems. The Covid-19 virus pandemic has had a significant impact on the tourism industry, resulting in decreased revenues and visits. Individuals must reintroduce themselves to a normal way of life in order to maintain their mental health and safety. The relaxation of tourism industry activity began with the government's announcement of the new normal. To aid in the recovery of Indonesia's tourism industry, the Ministry of Tourism and Creative Economy (Kemenparekraf) will implement the CHS (Cleanliness, Health, and Safety) program in all tourist destinations. By way of the CHS Program, researchers tried to analyze the effect of implementing the CHS (Cleanliness, Health, \&Safety) protocol for tourism recovery in Bali. This research uses qualitative methods with a descriptive approach, data analysis using literature studies. The hope is that by implementing the CHS protocol (Cleanliness, Health, \& Safety) the number of tourists in Bali can increase.
\end{abstract}

Keywords: Tourism, CHS (Cleanliness, Health, \& Safety), New Normal

\section{INTRODUCTION}

Pandemi COVID-19 has caused obstacles throughout the country, including Indonesia. There was a slowdown in economic growth in the first three months of 2020 and decreased growth in the second and third quarters of 2020. The impact of pandemics on the economy on the informal sector because they have low incomes and low savings tends to have no insurance protection or savings and contract power status. [1] Some of the sectors experiencing a downturn in the COVID 19 pandemic are:

1) Accommodation and food supply sector. This has decreased output due decrease in number of visits local and foreign tourists, many incidents of cancellation from Government and private agencies activities such as meetings, meetings / meetings, and conferences in hotels.

2) Industrial sectors namely the Beverage Food Industry, experienced a decrease in output due to declining foreign demand, seen from data on exports of food and beverage commodities;

3) Train and air transportation decreased due to the small number of passengers also due to the cancellation of train and aircraft travel due to concerns about the spread of COVID-19.(2)
According to BPS, foreign tourists visiting Indonesia in early 2020 decreased by 7.62 percent compared to the 1.37 million foreign tourists who visited in December 2019. The decrease in visits was caused by the outbreak of Covid-19 at the end of January 2020.

Figure 1 Monthly Visits of Foreign Tourists 2019 Vs 2020

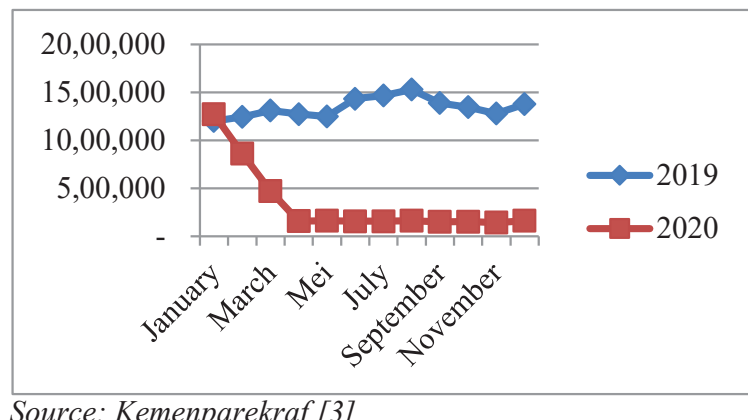

Source: Kemenparekraf [3]

Due to the Pandemic Covid-19, all activities in various sectors were suspended indefinitely to prevent the worsening spread of the Covid-19 tourism sector. With such widespread spread, it is consistent with Presidential Decree No. 12 of 2020, dated April 13, 2020, establishing non-natural disasters that spread Covid-19 as a National disaster [4]. The Covid-19 pandemic that hit Indonesia since March 2020, has had 
a negative impact on the economy of the People of Bali, especially from the tourism sector. Tourism, which is the backbone of the economy in Bali, was immediately paralyzed and helpless in the face of the ferocious covid-19 in Bali Province. the impact is tremendous, minus 12 percent of economic growth [5]. The Central Statistics Agency noted that foreign tourist visits (tourists) who entered Bali in 2020 from January to November always decreased very drastically.

Figure 2 . Number of Monthly Foreign Tourists to Bali According to Entrance (People) 2020

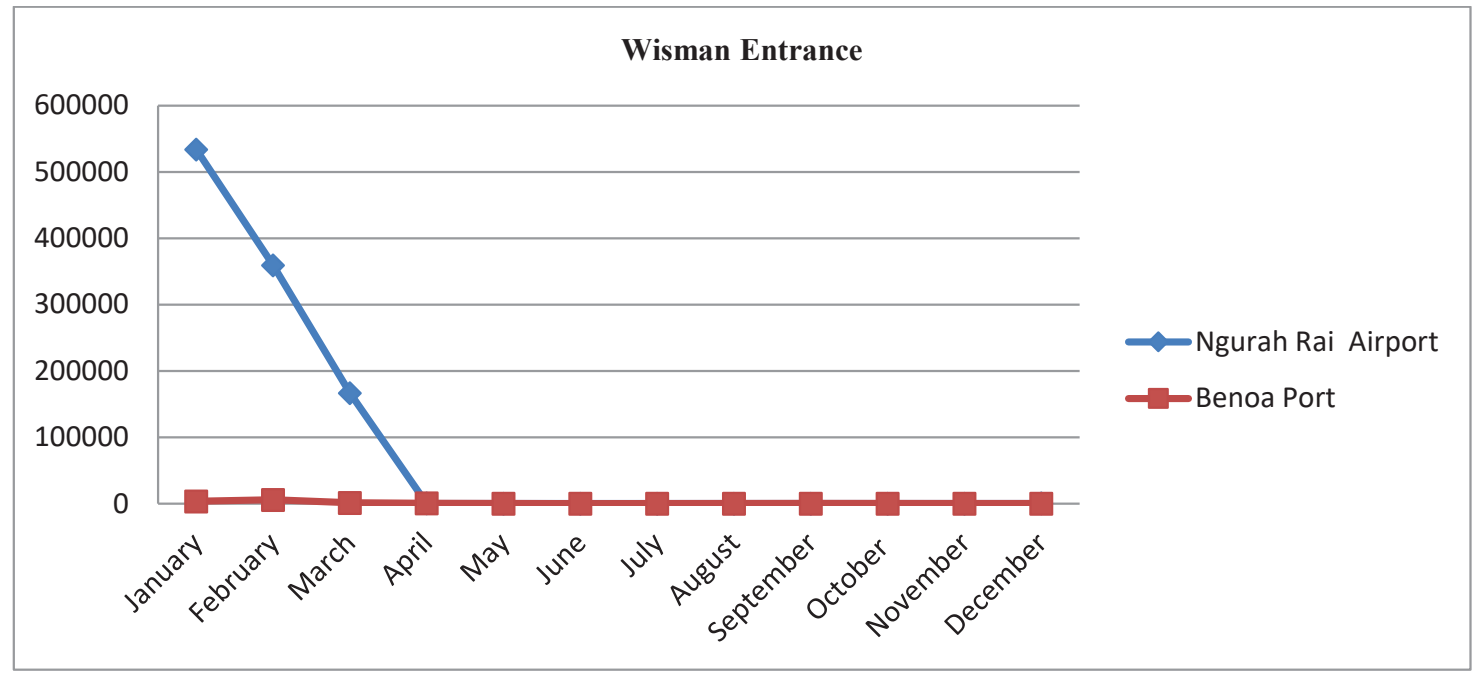

Source: BPS Provinsi Bali [6]

However, the government certainly does not want the slump and sluggishness of tourism will continue continuously. Interpreting the Ministry of Tourism and Creative Economy's (Kemenparekraf / Barekraf) progressive efforts to improve the quality of CHSEbased health protocols (Cleanliness, Health, Safety, and Environment) implementation for tourism and creative economy businesses [7].

\section{RESEARCH METHODS}

Bali Tourism Recovery Efforts research in the New Normal Erauses qualitative descriptive statistical analysis methods to understand the phenomenon of the Covid 19 Pandemic that threatens the economic downturn of one of the tourism industry sectors in Indonesia. The data in this study are based on a review of the literature in the form of articles, books, literary works, and journals pertaining to the tourism industry and its recovery during the pandemic era [8]. This research uses secondary data that is data that is used as supporting material from research writing in another sense as a source of information that does not directly have authority and information [9]. In this study, secondary data were taken from BPS and Ministry of Tourism and Creative Economy data.

\section{RESULT AND DISCUSSION}

Impact of Covid19 on Tourism Tourism in Bali can be understood as a collection of multidimensional and multidisciplinary activities related to tourism that emerges as a form of individual and national needs and of interactions. between tourists and local residents, other tourists, local authorities and business people. With the Covid-19 pandemic, all activities in various sectors have been halted to prevent further spread of the tourism sector Covid-19 is no exception. In accordance with data from the Central Bureau of Statistics of Bali Province. Below we can see the arrival of foreign tourists to Bali.

Figure 3. Number of foreign tourist visits to Indonesia in $2018-2020$

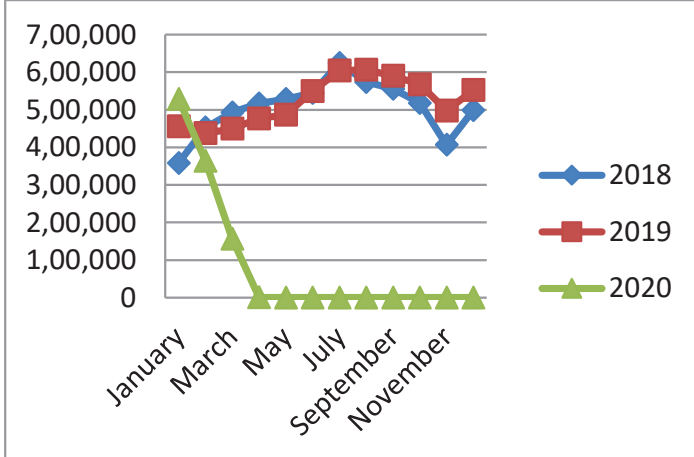

Source: BPS Bali Province

The data above shows a very drastic search of foreign tourist visits from the beginning of 2020 to July 2020, compared to 2018-2019. This is due to 
restrictions on visits from various countries due to the Covid-19 pandemic that hit almost the entire world. However, the existing conditions with the Covid-19 pandemic phenomenon resulted in this sector experiencing a very large adverse impact. To improve the tourism sector, The Ministry of Tourism and Creative Economy has tasked all tourism industries with the responsibility of implementing CHSE development (Cleanliness, Health, Safety, Environment).

The CHSE protocol of the Department of Tourism and Creative Economy is the policy of the Department of Tourism and Creative Economy as a guide for entrepreneurs and/or local managers, guides and employees of tourist attractions in adapting to new habits in the form of instructions for tourism businesses, attractions and other tourism products to apply guarantees to tourists of clean practice, health, safety and environmental sustainability. CHSE is the implementation of health protocols based on Cleanliness, Health(Health), Safety, and Environment Sustainability. Kemenparekraf as an institution that houses the tourism sector and creative economy promotes the CHSE health protocol so that it can be implemented by community business entities. The implementation of clean, healthy, safe and sustainable sanitation (CHSE) or hereinafter referred to as the Guidelines for the implementation of clean, healthy, safe and sustainable sanitation and environmental protection in tourist attractions are operational guidelines of Minister of Health Decree. Issuing HK.01.07 / Menkes / 382/2020 on health care procedures for people in public places and facilities to prevent and control Corona virus disease in 2019 (Covid-19). CHSE has been implemented in the tourism and creative economy sector in Indonesia since September 2020. It is useful for employers and/or local managers, employees and tour guides to meeting the needs of tourists for clean, healthy, safe and environmentally friendly tourism products and services during the Covid19 pandemic. The preparation of the orientation involves different parties, namely trade and professional associations related to tourist attractions, managers of tourist villages, tourism leadership groups/groups conscious of travel and academics. The goals of the CHSE protocol are:

a. Raising awareness among Indonesians and the world about cleanliness, health, safety and environmental sustainability is very important due to the Covid19 pandemic.

b. Future patterns of tourist needs and behavior will be greatly influenced by perceived high levels of hygiene, health, and safety, as well as environmental sustainability.

c. The world of tourism must be prepared to be able to provide high guarantees of the products and services provided to tourists must be clean, healthy, safe, and environmentally sustainable.

d. The key to becoming a major tourist attraction is The term "tourist attraction" refers to anything that possesses uniqueness, beauty, and value in the form of natural resources, culture, and man-made products. are destinations that have been chosen or visited.

e. Practical advice is needed for tourist destinations in the preparation of clean, healthy, safe and environmentally friendly products and services.

In addition, there are also several criteria in the implementation of CHSE-based health protocols:

Cleanliness: In the aspect of cleanliness, in general, business people must ensure cleanliness in their place of business, such as the availability of handwashing soap or hand sanitizer for visitors. Ensuring the business premises are always clean, whether from germs, bacteria, and viruses by spraying disinfectants is also a requirement in meeting this aspect.

Health: In maintaining health in the business area, business people need to maintain the health of both workers and visitors. Starting from checking body temperature, wearing masks, to applying social restrictions with setting distance and minimizing crowds.

Safety: To maintain safety and security, businesses need to prepare rescue procedures in case of an unwanted disaster or emergency. It aims to ensure the safety of those within the area.

Environment Sustainability: Businesses need to ensure that their businesses have implemented environmentally friendly conditions. For example, with the use of environmentally friendly equipment and materials, to condition the area, so that it feels comfortable for visitors.

"For the recovery of Indonesian tourism as well as Bali tourism in particular, the government has issued several policy measures. On May 29, 2020, the Ministry of VAT / Bappenas formulated the Covid-19 Productive and Safe Society Protocol towards a new normal, coexisting with Covid-19. Based on the experience of other countries' success in dealing with the Covid-19 pandemic, some of the main prerequisites needed to ensure the productivity and safety of the community are:

1) The use of data and science as a basis for decision-making for the reduction of LargeScale Social Restrictions (PSBB);

2) Reduction of PSBB is carried out through several stages and zones;

3) The implementation of strict health protocols through discipline and supervision by the apparatus;

4) Review of the implementation of PSBB reduction that can cause a deterrent effect so 
that there is a possibility of strict re-enactment of PSBB if the community is not disciplined in its activities.

This prerequisite is to determine the criteria of health measures in determining PSBB reduction [10] policies. Kemenparekraf itself assesses that the main key in the return of conditions must be done through disciplined health protocols. This program comes as an effort by the government in creating a safe and comfortable space for the community."The beach area is one of the potentials that need to be developed because it has an attraction in Bali. In addition, the coastal area also has a role in the prevention of direct tides on land, salt management efforts, and recreation areas as an asset of Bali's unique culture. The purpose of the development is to realize a clean, healthy, safe beach environment and can improve environmental conservation for the local community.

Table 1. Number of Foreign Tourist Visits to Indonesia 2020- June 2021

\begin{tabular}{|l|c|c|}
\hline \multicolumn{1}{|c|}{ Moon } & $\mathbf{2 0 2 0}$ & $\mathbf{2 0 2 1}$ \\
\hline January & 528.883 & 10 \\
\hline February & 363.937 & 12 \\
\hline March & 156.876 & 3 \\
\hline April & 379 & 9 \\
\hline May & 36 & 8 \\
\hline June & 45 & 1 \\
\hline July & 16 & - \\
\hline August & 12 & - \\
\hline September & 8 & - \\
\hline October & 63 & - \\
\hline November & 53 & - \\
\hline December & 150 & $\mathbf{4 3}$ \\
\hline Sum & $\mathbf{1 . 0 5 0 . 4 5 8}$ & - \\
\hline
\end{tabular}

Source: Central Bureau of Statistics of Bali Province

If you look at the presentation of table data 1.3 above it can be concluded that the number of tourist visits per month since the implementation of the CHSE protocol in September 2020 there was a slight increase in the number of tourists. But entering the beginning of 2021 in January there was a drastic decline of approximately $93 \%$. The decline in a sustainable manner will certainly put very heavy pressure on the Economy of Bali and the life of the people of Bali in particular. Therefore, we must prepare as tourism actors in Indonesia, Bali especially after this pandemic ends is the signature of health and security is the main thing that must be considered by the government along with tourism industry managers. Then try to prepare some new travel alternatives in the pandemic period that still attract tourists but are safe and can be run by paying attention to health protocols. The result was the establishment of the concept of protocols for CHSE and posters as a persuasive effort to visitors and all stakeholder to perform the CHSE system. According to the authors of the implementation of the CHSE protocol (Cleanliness, Health, Safety, Environment) at the beginning of implementation is considered effective because of the increase in the number of visitors but entered the beginning of the year precisely in January 2021. Entering February to June also experienced an increase in the number of tourists. The CHSE programhasbeen implemented in the tourism sector and creative economy, and this is expected to stimulate tourism activities in Bali in particular.

\section{CONCLUSION}

Based on the discussion above, it can be concluded First, Bali as an international tourism destination with Cultural tourism as a tourist attraction has increased the number of visits from year to year this can be seen from BPS data on the rate of foreign tourist visits from 2014-2015 grew 6.24\%, 2015-2016 tumbh 23\%, 2016 2017 grew $15 \%, 2017-2018$ grew $3 \%$,

Second, conversely there is a decrease in tourists who travel to Bali starting from March 2020. March was the first time the first case of covid 19 was announced in Bali. Until the closure of Bali tourism for foreign tourism is very destroying all economic lines in Bali.

Third, Adaptation is something that must be applied because all parties must be able to adapt to the conditions of the Covid-19 pandemic, namely by continuously increasing the application of 'CHSE' aka Cleanliness (Hygiene), Health (Health), Safety (Security), and Environment (Environmentally Friendly).

\section{REFERENCES}

[1] ILO. (2020). https://www.ilo.org/wcmsp5/groups/ public/---dgreports/gender/documents/publication/wcms _744685.pdf. \%0A

[2] Tusianti, E. P. (2020). Buku Analisis Isu Terkini 2020. BPS RI 2020.

[3] Kemenparekraf. (2020).

[4] Kristina, N. M. (2020). Pemulihan Ekonomi Pariwisata Bali di Era New Normal . Cultoure, 136-142.

[5] Herdiana, D. (2020). Rekomendasi Kebijakan Pemulihan Pariwisata Pasca Wabah Corona Virus 
Disease 2019 (Covid-19) Di Kota Bandung. Jurnal Master Pariwisata , 1-30.

[6] BPS Provinsi Bali. (n.d.). Retrieved from https://bali.bps.go.id/indicator/16/106/2/banyaknya -wisatawan-mancanegara-bulanan-ke-balimenurut-pintu-masuk.html.

[7] I Made Wimas Candranegra, I Wayan Mirta dan Kadek Agus Febriana Putra. (2021). Implementasi Program " We Love Bali" Berbasis CHSE (Clean, Health, safety, environment) dalam pemulihan Pariwisata Bali. Journal of Contemporary Public Administration (JCPA) , 27-37.
[8] Arikunto, S. (2010). Metode Peneltian. Rineka Cipta.

[9] Sugiyono. (2010). Metode Penelitian Pendidikan Pendekatan Kualitatif, Kuantitatif dan $R \& D$. Bandung: Alfabeta.

[10] Paramita, I. B. G., \& Putra, I. G. G. P. A. (2020) New Normal Bagi Pariwisata Bali Di Masa Pandemi Covid 19. Jurnal Ilmiah Agama Dan Budaya, 57-65. 